UDC 577.1+ 612.1

\title{
MEMBRANE-BOUND HEMOGLOBIN AS AN INDICATOR OF NITRIC TOXICITY OF ERYTHROCYTES
}

\author{
S.Y.Huseynova \\ Institute of Biophysics, NAS of Azerbaijan \\ s.huseynova@biophys.science.az
}

Received 19.09.2019

Accepted 17.12.2019

\begin{abstract}
The effect of sodium nitrite $\left(\mathrm{NaNO}_{2}\right)(0.07-3.50 \mathrm{mM})$ and sodium selenite $(10 \mu \mathrm{M})$ on the oxidation of hemoglobin $(\mathrm{Hb})$ and lipid peroxidation (LPO) in human red blood cells in vitro is examined. It was revealed that nitrites have a significant effect on oxidative processes in $\mathrm{Hb}$ and to a lesser extent in erythrocytes, and sodium selenite weakens the development of the nitrite-induced oxidative process in erythrocytes and reduces the formation of methemoglobin $(\mathrm{MetHb})$ by $12-25 \%$. Having a significant effect on the oxidative modification of $\mathrm{Hb}$, nitrites at moderate concentrations do not lead to a noticeable increase in lipid peroxidation in erythrocytes. Under the influence of high $\mathrm{NaNO}_{2}$ concentrations (3.50 $\mathrm{mM})$, an increase in the accumulation level of MetHb by ten leads to an increase in the accumulation of thiobarbituric acid (TBA) active products by $40-70 \%$. If at a low final concentration of nitrite $(0.07$ $\mathrm{mM}$ ) there is no noticeable change in the content of total membrane-bound hemoglobin (oxyHb and $\mathrm{MetHb})$, then at a moderate $(0.70 \mathrm{mM})$ and high $(3.50 \mathrm{mM})$ concentration these changes are obvious 10 and $15 \%$, respectively. Introduced into the incubation medium before and after incubation with nitrite, sodium selenite with concentration $10 \mu \mathrm{M}$ has a certain inhibitory effect on this process.
\end{abstract}

Keywords: sodium nitrite, sodium selenite, red blood cells, hemoglobin.

doi.org/10.32737/0005-2531-2020-2-67-73

\section{Introduction}

One of the acute and chronic nitrate-nitrite intoxications is associated with metgemoglobinemia and hypoxia, wich leads to multiple changes in the organs and tissues [1]. Nitrite is able to have an impact on all structural-functional levels, from the entire organism to the single molecule. Underlying systemic mechanisms of that influence is the reaction of transformation nitrite-ions to monoxide nitrogen (NO) [2].

Not only nitrogen oxide has physiological activity, but also numerous products of its transformation [3]. One of them is ONOO strong oxidizer and nitrifying agent, which is product interaction between nitrogen oxide and superoxide anion $\left(\mathrm{O}_{2}^{-*}\right)$. The main target of peroxynitrite is also hemoglobin. The interaction of peroxynitrite with oxy- and deoxyhemoglobin leads to the formation of methemoglobin and further modified $\mathrm{Hb}$ derivatives [4].

$\mathrm{OxyHb}$ reacts with peroxynitrite to produce feryl $\mathrm{Hb}$, nitrite and molecular oxygen (equation 1) [5]:

$$
\begin{aligned}
& \mathrm{Hb}\left(\mathrm{Fe}^{\mathrm{II}}\right) \mathrm{O}_{2}+\mathrm{ONOOH} \rightarrow \mathrm{Hb}\left(\mathrm{Fe}^{\mathrm{IV}}\right)=\mathrm{O}+\mathrm{O}_{2}+ \\
& +\mathrm{NO}_{2}{ }^{-}
\end{aligned}
$$

With oxyHb-mediated oxidation of $\mathrm{NO}$, the metHb-peroxynitrite complex decomposes to metHb and nitrate (equation 2): $\mathrm{Hb}\left(\mathrm{Fe}^{\mathrm{II}}\right) \mathrm{O}_{2}+\mathrm{NO} \rightarrow \mathrm{Hb}\left(\mathrm{Fe}^{\mathrm{III}}\right)-\mathrm{OONO} \rightarrow$ $\rightarrow \mathrm{Hb}\left(\mathrm{Fe}^{\mathrm{III}}\right)+\mathrm{NO}_{3}^{-}$

One of the physiologically significant complexes of nitric oxide formed in the blood generated by nitrite is the NO complex associated with heme of hemoglobin [6]. An excessive amount of nitrates transfers the heme iron from the $\mathrm{Fe}^{2+}$ to the $\mathrm{Fe}^{3+}$ state (MetHb), which is an abnormal form for hemoglobin, since it loses the ability to supply body's tissues with oxygen. And in those cases when the methemoglobin reductase system of erythrocytes is not able to cope with an excess of $\mathrm{MtHb}$, or when a large amount of $\mathrm{Hb}$ is irreversibly converted by $\mathrm{HbNO}$, pathological conditions may occur due to a violation of the oxygen transport properties of intraerythrocytic $\mathrm{Hb}[7,8]$.

MetHb reduction mechanisms [9]: 


$$
\begin{aligned}
& \mathrm{NADFH}+\mathrm{HbFe}(+3)-\mathrm{OH} \stackrel{\mathrm{NADFH}-M e t H b r e d u c t a s e}{\longrightarrow} \mathrm{HbFe}(+2)+\mathrm{NADF} \\
& \mathrm{NADH}+\mathrm{HbFe}(+3)-\mathrm{OH} \stackrel{\mathrm{NADH}-M e t H b r e d u c t a s e}{\longrightarrow} \mathrm{HbFe}(+2)+\mathrm{NAD}
\end{aligned}
$$

Reactions between $\mathrm{Hb}$ and $\mathrm{O}_{2}$ or NO (reactions with one hemoglobin heme group) [10]:

$$
\begin{aligned}
& \mathrm{Hb}^{2+}+\mathrm{O}_{2} \leftrightarrow \mathrm{Hb}^{2+} \mathrm{O}_{2} \\
& \mathrm{Hb}^{2+} \mathrm{O}_{2} \leftrightarrow \mathrm{Hb}^{3+}+\mathrm{O}_{2}^{-} \\
& \mathrm{Hb}^{2+}+\mathrm{NO} \leftrightarrow \mathrm{Hb}^{2+}-\mathrm{NO} \\
& \mathrm{Hb}^{2+} \mathrm{O}_{2}+\mathrm{NO} \leftrightarrow \mathrm{Hb}^{3+}+\mathrm{NO}_{3}^{-}
\end{aligned}
$$

a) the formation of oxyHb; $b$ ) the interaction of $\mathrm{O}_{2}$ with $\mathrm{Hb}$ also leads to the oxidation of $\mathrm{Hb}$, in which $\mathrm{O}_{2}$ is reduced to superoxide anion by oxidation of heme iron to $\mathrm{Fe}^{3+}$ with the formation of $\mathrm{MetHb}$; ) the formation of nitrosyl $\mathrm{Hb}\left(\mathrm{Fe}^{2+}-\mathrm{NO}\right) ; d$ ) NO can oxidize oxyHb with the formation of MetHb and nitrate.

Nitrite intoxication also has a significant membrane-toxic effect. There is information in the literature that under the influence of oxidizing factors, aggregates of hemoglobin and its derivatives are formed with their introduction into erythrocyte membranes [11]. The amount of membrane-bound hemoglobin increases with increasing levels of MetHb in the cell. Membrane-bound hemoglobin (MBH) plays an important role both in the formation and maintenance of erythrocyte cytoskeleton stability and in the mechanisms of enzymatic catalysis and intracellular energy transformation [12-14].

An endogenous antioxidant (AO) system is involved in the regulation of the level of oxidative processes in living organisms. Among its important components that regulate the level of oxidative processes in living organisms is the essential trace element selenium, which is part of 25 human proteins, some of which have antioxidant (AO) properties [15].

In this regard, clarification of the effects of subtoxic and toxic doses of nitrites on hemoglobin, the participation of hemoglobin and its derivatives in the destruction of erythrocyte membranes, as well as consideration of the participation of sodium selenite in the possible protection of hemoglobin and red blood cells in general from nitritin-induced oxidative modification is of particular interest, which is the purpose this study.

\section{Materials and methods}

The following reagents were used in the work: sodium nitrite $\left(\mathrm{NaNO}_{2}\right)$, sodium selenite $\left(\mathrm{Na}_{2} \mathrm{SeO}_{3}\right) \leq 99 \%$ (SIGMA-ALDRIC CHEMIE $\mathrm{GmbH}$ ) trichloroacetic acid (TCA) $10 \%$ solution, thiobarbituric acid (TBA) $0.5 \%$ solution, $0.9 \% \mathrm{NaCl}$ solution, sodium phosphate buffer solution (NPF) (10 mM NPB pH 7.4) (all reagents of Russian production, chemical grade). All measurements were performed on SF-46 spectrophotometer (Russia).

In model experiments, human erythrocytes were used as an object of study. In vitro experiments, donor blood was used, taken from the ulnar vein into test tubes with heparin (20 units $/ \mathrm{ml}$ of blood). Centrifugation $(800 \mathrm{~g} / 10 \mathrm{~min})$ was used to separate blood plasma from red blood cells. To obtain a erythrocyte suspension, the erythrocyte sediment was washed three times in a tenfold volume of the NPB solution, centrifuged at $800 \mathrm{~g}$ for $15 \mathrm{~min}$, followed by removal of the supernatant. Erythrocyte hemolysis was achieved by diluting the erythrocyte mass with distilled water in a ratio of 1:9, followed by freezing, thawing, and centrifugation at $10000 \mathrm{~g} / 10 \mathrm{~min}$. Nitrite exposure was carried out with sodium nitrite, the final concentration in the incubation medium ranged from 0.07 to $3.50 \mathrm{mM}$ (exposure time from 0 to 60 min). Sodium selenite was used as a possible AO factor that affects oxidative processes, which has high permeability through the erythrocyte membrane and active metabolism in them. Sodium selenite was introduced into the incubation medium at a final concentration $(10 \mu \mathrm{M})$.

The level of MBH in erythrocytes was determined spectrophotometrically by the difference in extinctions at the corresponding wavelengths (oxyHb (540, $577 \mathrm{~nm})$, MetHb (630 nm)) before and after centrifugation $(1000 \mathrm{~g} / 10 \mathrm{~min})$ of the 
lysate. A decrease in the level of oxyHb and MetHb in supernatants indicated an increase in $\mathrm{MBH}$. The levels of oxyHb and MetHb were evaluated by semi-empirical formulas: $\mathrm{HbO}_{2}=$ $66 \mathrm{~A}_{577}-80 \mathrm{~A}_{630}$; MetHb $=279 \mathrm{~A}_{630}-3.0 \mathrm{~A}_{577}$

Given the significant differences in the rates of $\mathrm{Hb}$ oxidation in the time interval of 0 30 and $30-60 \mathrm{~min}$, two series of experiments with incubation periods of samples (30 and 60 min) at a temperature of $37^{\circ} \mathrm{C}$ were carried out to evaluate the ratios of nitrite oxidized forms of $\mathrm{Hb}$ in erythrocytes. Each series included one control and test samples. The control sample contained $2.0 \mathrm{ml}$ of a suspension of red blood cells $+0.2 \mathrm{ml}$ of buffered saline, and the experimental sample contained $2.0 \mathrm{ml}$ of a suspension of red blood cells and $\mathrm{NaNO}_{2}(0.2 \mathrm{ml})$ with various final concentrations in the test material.

The level of lipid peroxidation of erythrocyte was evaluated by the accumulation of colored oxidation products that react in a color reaction with thiobarbituric acid (TBA) [16]. When some of the oxidized lipids interact with TBA at $t=90-100^{\circ} \mathrm{C}$, a colored trimethine complex is formed with maximum absorption of $532 \mathrm{~nm}$.

Statistical processing of the results was performed using the $t$-test at a significance level of $p<0.05$ [17].

\section{Results}

A preliminary series of experiments to clarify the patterns of MetHb accumulation in an incubation medium containing red blood cells, depending on the content of sodium nitrite in it and the incubation time, showed that already in the first $5 \mathrm{~min}$ of incubation (at $37^{\circ} \mathrm{C}$ ), an oxidative modification of $\mathrm{Hb}$ takes place, which reaches a maximum already in the first $15-30$ min and after a certain decline is (up to 2 hours of incubation) at a stable level. From used con- centrations, $0.7 \mathrm{mM}$ and higher $(3.50 \mathrm{mM})$ have a significant effect, which were used in the incubation time interval from 15 to $90 \mathrm{~min}$.

It is known that oxidized hemoglobin derivatives, settling in the erythrocyte membrane, cause oxidative modification of the membrane. In this regard, we examined the effect of sodium nitrite and sodium selenite with an incubation period of $15 \mathrm{~min}$ on the state of the content of membrane oxyHb and MetHb. The introduction of sodium nitrite into the incubation medium leads to their decrease in supernatants of erythrocytes after separation of erythrocyte membranes by centrifugation, which indicates their movement into the erythrocyte membrane, changing its physicochemical properties. There is an increase in the level of accumulation of MetHb and $\mathrm{oxyHb}$ in the membranes of erythrocytes with an increase in the concentration of sodium nitrite $0.07,0.70,3.50 \mathrm{mM}$ to $\approx 2,8$ and $12 \%$ for $\mathrm{MetHb}$ and $\approx 1,2$ and 3\% for oxyHb of their total initial content in erythrocyte supernatants (before centrifugation), respectively.

In the same way, the content of MetHb and oxyHb, formed upon nitrite exposure to $\mathrm{Hb}$ in the presence of sodium selenite, was estimated. The results show that in the presence of sodium selenite in the incubation medium, the content of membrane-bound or aggregated $\mathrm{Hb}$ and MetHb decreases to a certain extent (up to $24 \%$ ), which indicates the AO effect of selenite on the nitrite effect (Table 1).

$\mathrm{MetHb}$ accumulation reached its maximum stable level already in the first $30 \mathrm{~min}$.

Given this, it can be assumed that a longer nitrite effect does not play a significant role in enhancing the oxidizing effect, since the main oxidizing effect is achieved already in the first $30 \mathrm{~min}$ of incubation.

Table 1. The effect of $\mathrm{NaNO}_{2}(0.07,0.70,7.0 \mathrm{mM})$ and $\mathrm{Na}_{2} \mathrm{SeO}_{3}(10 \mu \mathrm{M})$ on the content of $\mathrm{MBH}$ in red blood cells.

\begin{tabular}{|c|l|c|c|c|}
\hline \multirow{2}{*}{$\begin{array}{c}\text { Concentration } \\
\mathrm{NaNO}_{2}\end{array}$} & \multicolumn{1}{|c}{ Wavelength, $\mathrm{nm}$} & $\lambda=540$ & $\lambda=577$ & $\lambda=630$ \\
\cline { 2 - 5 } & Camples & 0.010 & 0.030 & 0.330 \\
\hline \multirow{2}{*}{$0.07 \mathrm{mM}$} & $\mathrm{NaNO}_{2}$ & 1.120 & 0.100 & 0.060 \\
\cline { 2 - 5 } & $\mathrm{Na}_{2} \mathrm{SeO}_{3}+\mathrm{NaNO}_{2}$ & 1.000 & 0.090 & 0.040 \\
\hline \multirow{2}{*}{$0.70 \mathrm{mM}$} & $\mathrm{NaNO}_{2}$ & 0.024 & 0.036 & 0.760 \\
\cline { 2 - 5 } & $\mathrm{Na}_{2} \mathrm{SeO}_{3}+\mathrm{NaNO}_{2}$ & 0.018 & 0.024 & 0.580 \\
\hline \multirow{2}{*}{$3.50 \mathrm{mM}$} & $\mathrm{NaNO}_{2}$ & 0.017 & 0.018 & 1.350 \\
\cline { 2 - 5 } & $\mathrm{Na}_{2} \mathrm{SeO}_{3}+\mathrm{NaNO}_{2}$ & 0.012 & 0.013 & 1.080 \\
\hline
\end{tabular}


Figures 1 and 2 show the levels of MetHb accumulation in erythrocytes under the influence of both single and combined action of $\mathrm{Na}_{2} \mathrm{SeO}_{3}$ and $\mathrm{NaNO}_{2}$ at different incubation times. It can be seen, that sodium selenite somewhat reduces the oxidative effect of nitrite (12-24\%). Further, it was important to consider the effect of the combined action of nitrite and selenite on the state of lipid peroxidation of red blood cells. It turned out that, despite the fact that nitrites actively increase the generation of MetHb (by a factor of ten), which is an important prerequisite for the development of lipid peroxidation, given the standard hypothetical chain for the development of oxidative destruction of red blood cells: $\mathrm{Hb} \rightarrow$ MetHb $\rightarrow$ feryl hemoglobin $\rightarrow$ SH destruction of $\mathrm{SH}$ groups $\rightarrow$ aggregation (Heinz body) $\rightarrow$ oxidation of membrane lipids, the LPO intensity increased at a nitrite concentration of $0.70 \mathrm{mM}$ to $40 \%$, and at a concentration of $3.50 \mathrm{mM}$ to $70 \%$.

The sequence of introducing nitrite and selenite into the incubation medium with red blood cells does not play a role in changing the level of accumulation of MetHb and lipid peroxidation, which is associated with rapid penetration (in particular, for selenium it takes several minutes) through the erythrocyte membrane the level of which is kept at stationary for 30 minutes or more relatively low.
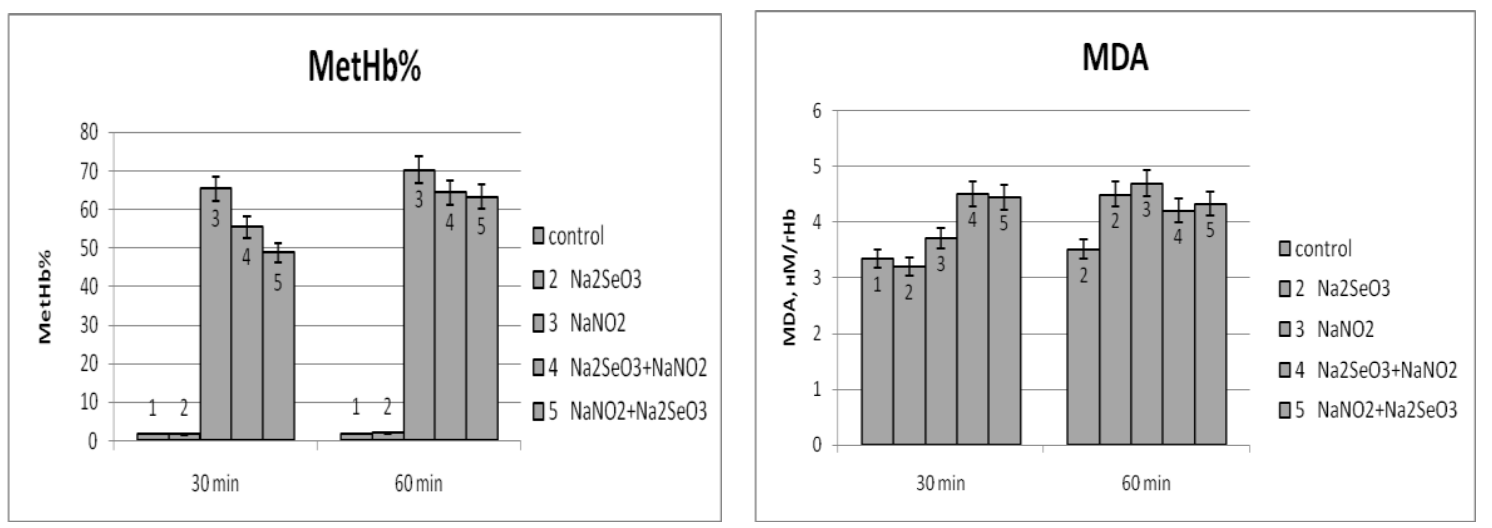

Fig. 1. Accumulation of MetHb, LPO products (MDA), incubated $\left(37^{\circ} \mathrm{C}\right)$ in a medium containing $\mathrm{NaNO}_{2}$ $(0.70 \mathrm{mM})$ and $\mathrm{Na}_{2} \mathrm{SeO}_{3}(10 \mu \mathrm{M})$ for 30 and $60 \mathrm{~min}$.
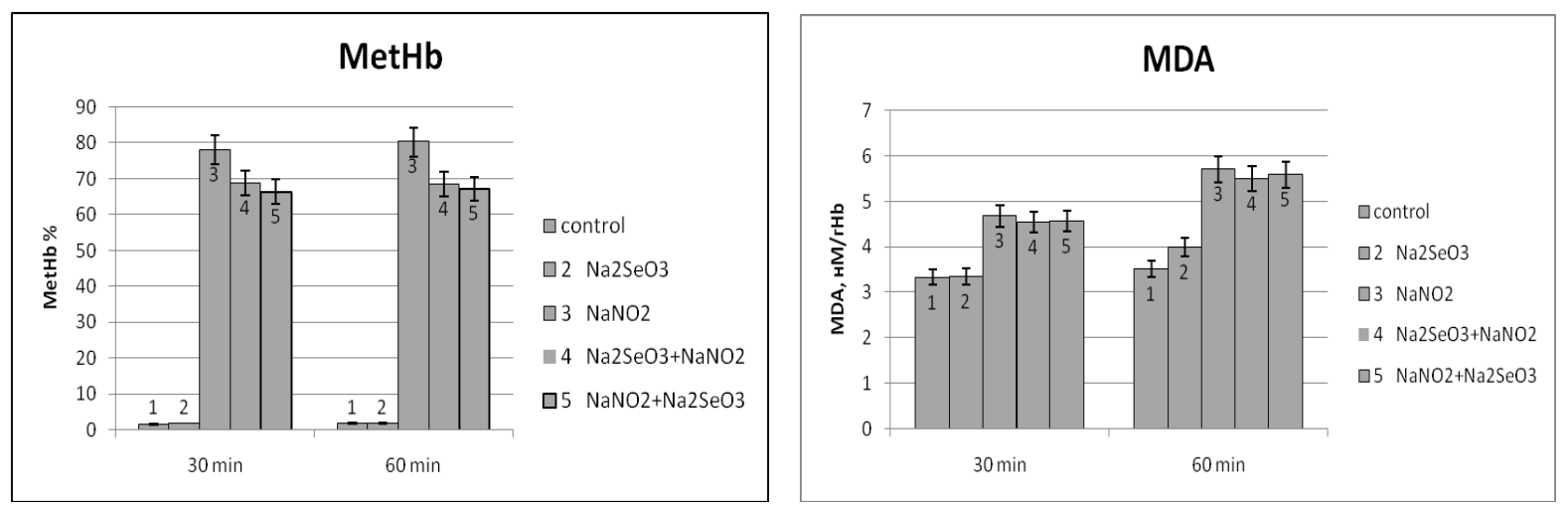

Fig. 2. Accumulation of MetHb, LPO products (MDA), incubated $\left(37^{\circ} \mathrm{C}\right)$ in a medium containing $\mathrm{NaNO}_{2}$ $(3.50 \mathrm{mM})$ and $\mathrm{Na}_{2} \mathrm{SeO}_{3}(10 \mu \mathrm{M})$ for 30 and $60 \mathrm{~min}$ 


\section{Discussion}

The small size and lack of charge in the NO molecule formed in the incubation medium containing erythrocytes under nitrite exposure provides them with high permeability through the erythrocyte membranes and, accordingly, contact with $\mathrm{Hb}$ with the formation of various complexes [18]. In the model system, NO can nitrize heme iron, be included in hemoglobin as part of a dinitrosyl complex, and form hemoglobin nitrosothiol (Hb-SNO) [19]. Considering that the affinity constant of nitric oxide to the iron atom of porphyrin is much higher than that of oxygen, it competes with it for binding to hemoglobin [20]. The latter contributes to a change in the conformation of hemoglobin, and as a result, its affinity for oxygen [21]. The binding NO molecule to $\mathrm{SH}$-groups of cysteine$\beta 93$ can also affect the affinity of hemoglobin for oxygen and the stabilization of the T-state (this state is characterized by a low affinity for oxygen) [22]. Ultimately, an increase in the affinity of hemoglobin for oxygen by nitrite stimulates the oxidative modification of the protein, i.e. the formation of MetHb and other oxidation products, and also accelerates the LPO reaction.

The relatively low degree of intensification of lipid peroxidation of erythrocytes (4070)\% along with a significant oxidative effect on $\mathrm{Hb}$ (a tenfold increase in MetHb content), indicates that MetHb formed in large quantities, and possibly other products of nitrite interaction (nitric oxide) and hemoglobin can inhibit the development of LPO reactions, i.e. act as AO [23]. An increase in the concentration of nitrite in the incubation medium leads to an increase in membrane oxyhemoglobin and MetHb. All this contributes to both the intensification of lipid peroxidation of erythrocytes and the modification of protein components of the membrane apparatus [24].

Regarding the AO action of selenium, it should be noted that hemoglobin itself, being a selenoprotein, non-stoichiometrically absorbs selenium, which, substituting sulfur, is supposedly localized in cysteine- $\beta 93 \mathrm{Hb}$ [25] and has a certain $\mathrm{AO}$ effect $[26,27]$. It is characteristic that in all cases, selenium (sodium selenite) intro- duced into the incubation medium in the first minutes in the range of $0-0.5$ hours is actively included in the hemoglobin fraction and, enhancing the $\mathrm{AO}$ properties of hemoglobin, to some extent weakens the development of the induced oxidative process ( both the accumulation of MetHb and LPO reactions). And in our case, this means, judging by the literature data, that selenium incorporated into the hemoglobin molecule from the incubation medium is localized, replacing sulfur, in the proximal portion of the $\beta$ chain in the position of cysteine-93 in close proximity to the heme, and also, possibly and other hemoglobin $\mathrm{SH}$ groups attacked by nitric oxide [28]. It follows that the selenium and nitrogen monoxide included in $\mathrm{Hb}$, being in close proximity to each other, mutually influence the effects they produce, including those of an oxidizing nature.

\section{References}

1. Gladwin M.T., Grubina R., Doyle M.P. The New Chemical Biology of Nitrite Reactions with Hemoglobin: R-State Catalysis, Oxidative Denitrosylation, and Nitrite Reductase/Anhydrase. 2009 Jan 20. 42(1). P. 157-67.

2. Omar S.A., Webb A.J., Lundberg J.O., Weitzberg E. Therapeutic effects of inorganic nitrate and nitrite in cardiovascular and metabolic diseases. J. Int. Medicine. 2016. 279. P. 315-336.

3. Osipov G.G., Borisenko IU.A., Vladimirov A.N. Biologicheskaia rol nitrozilnykh kompleksov gemoproteinov. Uspekhi biologicheskoi khimii. 2007. T. 47. S. 259-292.

4. Zinchuk V.V., Stepuro T.L. The Effect of Peroxynitrite on the affinity of hemoglobin for oxygen in vitro. Biophysics. 2006. V. 51. No 1. P. 23-28.

5. Romero N., Radi R., Linares E., Augusto O., Detweiler C.D., Mason R.P., Denicola A. Reaction of human hemoglobin with peroxynitrite. Isomerization to nitrate and secondary formation of protein radicals. J. Biol. Chem. 2003.V. 278. No 45. P. 44049-44057.

6. Shumaev K.B., Kosmachevskaya O.V., Tapunov A.F. Oksid azota s gemoglobinom i ne tolko. Khimiia i zhizn. 2008. № 4. S. 22-25.

7. Helms C., Kim-Shapiro D.B. Hemoglobin-mediated nitric oxide signaling. Free Radic. Biol. Med. 2013. V. 61. P. 464-472.

8. Stepuro T.L., Zinchuk V. Nitric oxide effect on the hemoglobin-oxygen affinity. J Physiol. Pharmacol. 2006. V. 57. No 1. P. 29-38.

9. Kutzsenko S.A. Osnovy toksikologii. SanktPeterburg: Izd-vo Folyant, 2002. 570 s. 
10. Crawford J. H., Chacko B. K., Patel R.P. Regulation of vascular function by haemoglobin. Biochem. Soc. Symp. 2004. V. 71. P. 135-422.

11. Low P.S. Role of hemoglobin denatyration and band 3 clustering in initiating red cell removal. In: Red Blood Cell Aging (Magnani M. De Flora A. eds). New York: Plenum Press, 1991. P. 173-183.

12. Kuznetzsova E.E., Pivovarov Y.I., Sergeeva A.S. Vliyanie raznykh urovney membrannosvyazannogo gemoglobina na kolichestvennoe soderjanie belkov membrany eritrotzsitov i ikh vzaimosvyaz $\mathrm{u}$ bolnykh gipertonicheskoy boleznyu. Mejdunarodnyi jurnal prikladnykh i fundamentalnykh issledovanii. 2016. № 6-3. S. 480-484.

13. Tsuneshige A, Imai K, Tyuma I..The binding of hemoglobin to red cell membrane lowers its oxygen affinity. Biochem. 1987 Mar. V. 101. No 3. P. 695-704.

14. Elizabeth M., Welbourn, Michael T., Wilson, Ashril Yusof, Metodi V.Metodiev, Chris E.Cooper. The mechanism of formation, structure and physiological relevance of covalent hemoglobin attachment to the erythrocyte membrane. Free Radical Biology and Medicine. 2017 February. V. 103. P. 95-106.

15. Vyacheslav M. Labunskyy, Dolph L. Hatfield, Vadim N. Gladyshev. Selenoproteins: Molecular Pathways and Physiological Roles. Physiol Rev. 2014. Jul. V. 94. No 3. P. 739-777.

16. Szebeni J., Winterbourn C.C., Carrell R.W. Oxidative interactions between haemoglobin and membrane lipid. A liposome model. Biochem. J. 1984. V. 220. No 3. P. 685-692

17. Lakin G.F. Biometriya. M.: Vysshaia shkola, 1990. 352 p.

18. Mark W. Vaughn, Kuang-Tse Huang, Lih Kuo, James C. Liao. Erythrocyte Consumption of Nitric Oxide: Competition Experiment and Model Analysis. NITRIC OXIDE: Biology and Chemistry. 2001. V. 5. No 1. P. 18-31.

19. Christine Helms, Daniel B. Kim-Shapiro. Hemoglobin-mediated nitric oxide signaling. Free Radic. Biol. Med. 2013 Aug. P. 464-472.
20. Christine C. Helms, Mark T. Gladwin, Daniel B. Kim-Shapiro. Erythrocytes and Vascular Function: Oxygen and Nitric Oxide. Front Physiol. 2018. V. 9. P. 125.

21. Hobbs A.I., Gladwin M.T., Patel R.P., Williams D.L.H., Butler A.R. Haemoglobin: NO transporter, NO inactivator or none of the above. TRENDS in Pharmacological Science. 2002. V. 23. P. 406-411.

22. Bonavertura C. Effects of S-Nitrosation on Oxygen Binding by Normal and Sickle Cell Hemoglobin. J. Biological Chem. 1999. V. 274. No 35. P. 24742-24748.

23. Corinne C. Widmer, Claudia P. Pereira, Peter Gehrig, Dominik J. Schaer. Hemoglobin can attenuate hydrogen peroxide induced oxidative stress by acting as an antioxidative peroxidise. Antioxidants and Redox signalling. 2010. V. 12. No 2. P. 185-199.

24. Low P.S. Role of hemoglobin denatyration and band 3 clustering in initiating red cell removal. In: Red Blood Cell Aging (Magnani M, De Flora A, eds). New York: Plenum Press, 1991. P. 173-183.

25. Millar K.P., Sheppard A.D., Gardiner M.A. A comparison of the distribution of $\mathrm{Se}$ in proteins of blood, liver, and kidney from rats differing in selenium status. N.Z.J. Agr. Res.1972. V. 15. No 4. P. 756-777.

26. Huseynov T.M., Yakhyayeva F.R., Guliyeva R.T. The effect of selenium on the stability of hemoglobin to photooxidative processes. Ukrain. Biochem. J. 2012. V. 84. No 2. P. 53-60.

27. Huseynov T.M., Yakhyayeva F. R. Selenium as an antioxidant protector in the erythrocytes. Saarbruken, Germany. Lambert Academic Publishing, 2014. P. 134.

28. Benjamin Gaston, Walter J. May, Spencer Sullivan, Sean Yemen, Nadzeya V. Marozkina, Lisa A. Palmer, James N. Bates, Stephen J. Lewis. Essential role of hemoglobin beta-93-cysteine in posthypoxia facilitation of breathing in conscious mice. Appl. Physiol. 2014 May 15. V. 116. No10. P. 1290-1299.

\section{MEMBRANABAĞLI HEMOGLOBİN ERITROSITLəRIN NITRITT TOKSIKLIYYININ GÖSTəRICISİ KIMİ}

\section{S.Y.Hüseynova}

Natrium nitritin $\left(\mathrm{NaNO}_{2}\right)(0.07-3.50 \mathrm{mM})$ və natrium selenitin $(10 \mu \mathrm{M})$ insan qurmızı qan hüceyrələrində in vitro hemoglobinin $(\mathrm{Hb})$ oksidləşməsinə və lipid peroksidləşməsinə (LPO) təsiri araşdırılmışdır. Nitritlər Hb-də və daha az dərəcədə eritrositlərdə oksidləşmə proseslərinə əhəmiyyətli təsir göstərir, və natrium selenit eritrositlərdə nitritinlə induksiyalanmış oksidləşmə prosesinin inkişafını zəiflədir və methemoglobinin (MetHb) əmələ gəlməsini 12-25\% azaldır. Nitritlər hemoglobinin oksidləşdirici modifikasiyasına əhəmiyyətli dərəcədə təsir göstərərək, orta konsentrasiyalarda LPO aktivliyinin artmasına nəzərəçarpacaq dərəcədə səbəb olmur. $\mathrm{NaNO}_{2}$ yüksək konsentrasiyalarının (3.50 mM) təsiri altında MetHb-nin on dəfələrlə artması tiobarbitur turşusunın (TBT) aktiv məhsullarının toplanmasının artmasına 40-70\% gətirib çıxarır. Nitritin aşağı konsentrasiyasında $(0.07 \mathrm{mM})$ ümumi membrana bağlı hemoglobinin (oxyHb və MetHb) toplanmasında nəzərə çarpan dəyişiklik olmursa, orta $(0.70 \mathrm{mmol})$ və yüksək $(3.50 \mathrm{mM})$ 
konsentrasiyalarda bu dəyişikliklər aydın görünür 10 və $15 \%$. Nitrit ilə - inkubasiyadan əvvəl və sonra inkubasiya mühitinə daxil olan $10 \mu \mathrm{M}$ natrium selenit bu proseslərə müəyyən ləngidici təsir göstərir.

Açar sözlar: natrium nitrit, natrium selenit, eritrositlor, hemoglobin.

\section{МЕМБРАНОСВЯЗАННЫЙ ГЕМОГЛОБИН КАК ПОКАЗАТЕЛЬ НИТРИТНОЙ ТОКСИЧНОСТИ ЭРИТРОЦИТОВ}

\section{С.Ю.Гусейнова}

Рассмотрено влияние нитрита натрия $\left(\mathrm{NaNO}_{2}\right)(0.07-3.50 \mathrm{MM})$ и селенита натрия (10 $\left.\mu \mathrm{M}\right)$ на процессы окисления гемоглобина $(\mathrm{Hb})$ и перекисного окисления липидов (ПОЛ) в эритроцитах человека in vitro. Выявлено, что нитриты оказывают значительное воздействие на окислительные процессы в Нb и в меньшей степени в эритроцитах, а селенит натрия ослабляет развитие нитрит индуцированного окислительного процесса в эритроцитах и снижает образование метгемоглобина (MetHb) на 12-25\%. Оказывая значительное воздействие на окислительную модификацию $\mathrm{Hb}$, нитриты при умеренных концентрациях не приводят к заметному возрастанию показателей ПОЛ в эритроцитах. Под действием высоких концентраций $\mathrm{NaNO}_{2}(350 \mathrm{mM})$ увеличение уровня накопления МetНb в десятки раз приводит к возрастанию накопления активных продуктов тиобарбитуровой кислоты (ТБК) на 40-70\%. Если при низкой конечной концентрации нитрита (0.07 мМ) не происходит заметного изменения в содержании суммарного мембранного гемоглобина (охуНb и MetHb), то при умеренной $(0.70$ мМ) и высокой (3.50 мМ) концентрации эти изменения носят явный характер - 10 и 15\% соответственно. Вводимый в инкубационную среду до и после инкубации с нитритом селенит натрия в концентрации $10 \mu \mathrm{M}$ оказывает определенный тормозящий эффект на этот процесс.

Ключевые слова: нитрит натрия, селенит натрия, эритроциты, гемоглобин. 